\title{
Peran Angkutan Laut dalam Meningkatkan Distribusi Ternak Sapi Potong dari Daerah Produsen ke Wilayah Konsumen
}

\author{
The Role of Marine Transportation in Improving Livestock \\ Distribution from Producers to Consumers Region
}

\section{Bambang Winarso}

\section{Pusat Sosial Ekonomi dan Kebijakan Pertanian, Bogor}

\begin{abstract}
Nationally, there are some areas of the provinces in Indonesia is livestock center including East Nusa Tenggara province. East Nusa Tenggara Governor Decree No. 278/Kep/HK/2011 Deciding that the allocation of large livestock beef to local consumers (West Java, Jakarta and Kalimantan) each of (a) as 55.000 heads of cattle,(b) 7.000 buffalo and (c) 5.000 horse. For transporting live cattle the only means of transportation by ship. Darmaga Tenau in serving the transport of life cattle is still in a simple way. Similarly, in a transit Kalimas. In an effort to decrease the cattle of the ship had been taken in three ways: (a) transported and unloaded from boats using nets, $(b)$ direct the cows are herded through the bridge and (c) using containers. However, in connection with a number of criticisms relating to the principle Animal welfare, inevitably a third pattern to be implemented despite the fact that take a long time and ultimately costs more mahal. This paper is part of the research results of "Efisiensi Moda Transportasi Ternak dan Daging Sapi Dalam Mendukung Program Swasembada Pangan" by the Center for Economic and Agricultural Policy, 2013. Location of the study focused on East Nusa Tenggara and East Java.
\end{abstract}

Keywords: marine transportation, livestock, distribution

Diterima 12-02 2014, disetujui: 02-05-2014

\section{PENDAHULUAN}

Moda transportasi laut merupakan bagian dari pada moda transportasi lewat air, dimana kegiatan transportasi air disamping dapat dilakukan lewat laut, juga dapat dilakukan lewat sungai atau danau. Sarana yang digunakan untuk operasional transportasi/pengangkutan di laut berupa kapal, feri, dan sampan. Konsep dasar kegiatan pelayaran pada dasarnya adalah setiap distribusi barang, penumpang, hewan dan logistik yang membutuhkan alat angkut di perairan yang disebut kapal. Semua kapal yang melakukan kegiatan tersebut diatas bergerak dari satu titik (pelabuhan awal) ke titik lainnya (pelabuhan tujuan) dengan telah memenuhi persyaratan keselamatan dan keamanan berlayar. Berkaitan dengan kegiatan berlayar yang obyeknya adalah kapal, maka dalam hal niaga kapal yang digunakan adalah jenis kapal niaga yang berfungsi sebagai angkutan barang, penumpang maupun hewan. Keberadaan kapal niaga sendiri telah diatur dalam Undang-undang no. 17 tahun 2008 tentang pelayaran (Nikson, 2009).

Permasalahannya bahwa pengangkutan ternak lewat laut merupakan proses transportasi pengangkutan yang melewati jarak yang jauh, sehingga membutuhkan waktu yang cukup panjang 
untuk mencapai titik sasaran tujuan. Jarak yang jauh tersebut disamping berpengaruh terhadap biaya yang ditimbulkan juga berpengaruh terhadap kesehatan ternak.

Seperti yang dikemukakan oleh Tjeppy et al., 1995 menunjukkan bahwa biaya-biaya yang harus dikeluarkan dalam kegiatan transportasi ternak potong antar pelabuhan (pelabuhan pemberangkatan dan pelabuhan tujuan pengiriman ternak potong) diantaranya adalah: (a) Biaya pemuatan pelabuhan Tenau di Kupang, (b) Stasiun karantina, (c) jasa karantina yang terdiri dari biaya pakan, minum ternak, biaya makan dan upah tenaga pengurus ternak selama di karantina, (d) biaya kegiatan transportasi laut Kupang-Surabaya terdiri dari: freight kapal, pakan ternak, bambu penyekat (kandang), tali plastik, tali leher, obat-obatan (vitamin B-compleks dan terramicin), upah narik ternak, ongkos kelancaran pelabuhan, transport ternak ke tempat peristirahatan (peraktandes). Sementara Ilham (2009) juga mengemukakan bahwa makin panjang jarak tempuh pengangkutan ternak dari sentra produksi ke sentra konumsi makin banyak membutuhkan infrastruktur. Dengan demikian makin membutuhkan biaya yang lebih besar, karena dengan anggapan bahwa pedagang sapi merupakan pedagang bermodal besar selain dikenakan berbagai biaya pungutan resmi untuk PAD (Pendapatan Asli Daerah) juga pungutan biaya yang tidak rersmi.

Disamping adanya penyusutan ternak, Ilham dan Yusdja (2012) mengemukakan bahwa permasalahan lainnya adalah (a) Jumlah sapi yang semakin sedikit yang mengharuskan pedagang perlu mengumpulkan ternak yang akan diangkut sampai jumlah tertentu, hal ini tentu menimbulkan biaya terutama biaya pakan dan tenaga kerja selama ternak ada di penampungan, (b) sebelum sapi dimuat di kapal maka sebelumnya harus melalui pemeriksaan karantina sesuai aturan, hal ini dimaksudkan agar penyebaran penyakit menular ke tempat lain bisa dihindari, (c) Kapal pengangkut ternak umumnya bukan merupakan kapal khusus untuk ternak, sehingga disamping jadwal angkutan yang tidak jelas, maka dalam kegiatan pemuatan ternak perlu tambahan desain kandang ternak yang sifatnya darurat dan ini tentu menimbulkan biaya yang tidak sedikit.

Tulisan ini merupakan bagian dari hasil penelitian Kajian Efisiensi Moda Transportasi Ternak dan Daging Sapi Dalam Mendukung Program Swasembada Pangan yang dilakukan oleh Pusat Sosial Ekonomi dan Kebijakan Pertanian, Badan Litbang Pertanian, tahun 2013. Dalam tulisan ini lokasi penelitian lebih difokuskan pada wilayah Propinsi Nusa Tenggara Timur sabagai sentra produksi ternak sapi potong sekaligus sebagai wilayah pengiriman ternak. Propinsi tujuan ternak adalah Jawa Timur khususnya pelabuhan Tanjung Perak sebagai pelabuhan tujuan pengiriman ternak sapi potong.

\section{PEMBAHASAN}

\section{Pemuatan Sapi Potong di Pelabuhan Asal}

PT Pelabuhan Indonesia (Pelindo) III mencatat bahwa secara nasional menunjukkan bahwa realisasi arus hewan ternak yang berfluktuasi. Selama 2009 jika dibandingkan dengan realisasi arus hewan ternak tahun 2008 sebenarnya mengalami penurunan. Penurunan tersebut lebih disebabkan karena menurunnya arus pengiriman hewan dalam negeri khususnya pengiriman sapi bibit melalui pelabuhan Tenau- Kupang dan pelabuhan Bima yang dikirim ke wilayah Kalimantan. Sementara itu informasi tahun 2012 menunjukkan bahwa kegiatan angkutan luar negeri ternak sapi potong lebih didominasi adanya penurunan sapi impor yang pada tahun 2011 sebanyak 22,99 ribu ekor dan tahun 2012 turun menjadi 18,08 ribu ekor. Sedangkan kegiatan bongkar muat ternak selama tahun 2011 menunjukkan bahwa jumlah ternak yang diturunkan sebanyak 70,797 ribu ekor dan pada 
Bambang Winarso: Peran Angkutan Laut dalam Meningkatkan Distribusi Ternak Sapi Potong...

tahun 2012 turun menjadi 58,64 ribu ekor. Data pembongkaran dan pemuatan hewan ternak selama tiga tahun (2008-2010) di beberapa pelabuhan keragaannya ditampilkan dalam tabel 1 .

Tabel 1 Kegiatan bongkar-muat hewan ternak di beberapa pelabuhan selama tiga tahun (2008 2010)

\begin{tabular}{|c|c|c|c|c|c|c|}
\hline \multirow{2}{*}{ No } & \multirow{2}{*}{ Pelabuhan } & \multirow{2}{*}{ Kota } & \multirow{2}{*}{ Propinsi } & \multicolumn{3}{|c|}{ Tahun } \\
\hline & & & & 2008 & 2009 & 2010 \\
\hline $\mathbf{A}$ & Pembongkaran ternak & & & & & \\
\hline 1 & Tanjung Perak & Surabaya & Jawa Timur & 48.442 & 43.319 & $\operatorname{tad}$ \\
\hline 2 & Tanjung Intan & Cilacap & Jawa Tengah & 30.667 & 36.460 & $\operatorname{tad}$ \\
\hline 3 & Gresik & Gresik & Jawa Timur & 2.419 & 3.764 & $\operatorname{tad}$ \\
\hline 4 & Banjarmasin & Banjarmasin & Kalimantan Selatan & 16.791 & 12.960 & $\operatorname{tad}$ \\
\hline 5 & Sampit & sampit & Kalimantan Tengah & 195 & $\operatorname{tad}$ & $\operatorname{tad}$ \\
\hline 6 & Tanjungwangi & Banyuwangi & Jawa Timur & tad & $\operatorname{tad}$ & 2.419 \\
\hline B & Pemuatan ternak & & & & & \\
\hline 1 & Tenau & Kupang & Nusa Tenggara Timur & 36.857 & 41.286 & 36.296 \\
\hline 2 & Lembar & Lembar & Nusa Tenggara Barat & 9.639 & 5.599 & $\operatorname{tad}$ \\
\hline 3 & Bima & Bima & Nusa Tenggara barat & 28.992 & 15.285 & 8.905 \\
\hline
\end{tabular}

Sumber : PT Pelindo III, Laporan tahunan 2008 s/d 2012

Secara nasional ada beberapa wilayah propinsi di Indonesia yang merupakan daerah lumbung ternak diantaranya adalah wilayah Propinsi Nusa Tenggara Timor. Kasus di Propinsi Nusa Tenggara Timor (NTT) menunjukkan bahwa jumlah populasi ternak potong besar 2012 sapi potong sebanyak 814.449 ekor, kerbau 152.449 ekor dan kuda sebanyak 109.171 ekor. Dari jumlah tersebut pada tahun 2011 ternak besar yang keluar dari wilayah provinsi Nusa Tenggara Timur selama tahun yang sama sapi sebanya 63.449 ekor dan kerbau 4.607 ekor. Jumlah tersebut merupakan quota yang disetujui Gubernur pada tahun 2011 sebanyak 74.000 ekor, kerbau sebanyak 4.607 ekor dari quota sebanyak 7.250 ekor dan kuda sebanyak 4.986 ekor dari quota sebanyak 6.500 ekor (Dinas Peternakan Provinsi Nusa Tenggara Timur, 2012). Seperti diketahui bahwa saat ini pengeluaran ternak dari wilayah NTT telah diatur oleh pemerintah daerah setempat melalui sistim kuota.

Keputusan Gubernur Nusa Tenggara Timur No. 278/Kep/HK/2011 Memutuskan bahwa alokasi pengeluaran ternak besar potong dengan jumlah masing-masing (a ) sapi sebanyak 55.000 ekor, (b) kerbau sebanyak 7.000 ekor dan (c) kuda sebanyak 5.000 ekor. Sementara untuk tahun yang sama muncul kembali Keputusan Gubernur Nusa Tenggara Timur No. 207/Kep/HK/2012 Tentang Tambahan Alokasi Pengeluaran Ternak Besar Potong di Provinsi Nusa Tenggara Timur Thn 2012, yang memutuskan bahwa adanya tambahan alokasi pengeluaran ternak besar potong dengan jumlah masing-masing (a) sapi sebanyak 8.000 ekor, (b) kerbau sebanyak 150 ekor dan (c) kuda sebanyak 1.000 ekor. Dengan munculnya kebijakan quota tersebut tentu akan berpengaruh terhadap kinerja perdagangan sapi potong antar pulau.

Ilham dan Yusdja (2012) bahkan mengemukan bahwa dengan adanya sistim kuota, maka prospek usaha angkutan ternak sapi potong melalui laut kedepan diduga akan semakin memburuk baik dari sisi efisiensi maupun penggunaan jasa angkutan kapal. Hal ini diakibatkan oleh semakin berkurangnya jumlah ternak yang diperdagangkan antar pulau serta adanya batasan pengeluaran ternak (Quota) oleh pemerintah setempat. Bahkan Yusdja dan Ilham, 2004 juga mengemukakan bahwa kuota sebenarnya tidak memberikan pengaruh terhadap populasi ternak, pada kenyataannya 
pengurasan ternak terus terjadi di wilayah produksi. Jika kuota dilepas, maka jumlah sapi yang dikirim ke wilayah konsumen akan meningkat dan akibatnya harga sapi di wilayah produsen akan meningkat.

Kasus di wilayah provinsi Nusa Tenggara Timur (NTT) menunjukkan bahwa selama ini darmaga Tenau melayani pengangkutan ternak sapi potong hidup, juga melayani pengangkutan daging beku dengan menggunakan container dingin (River container) yaitu container yang dilengkapi dengan mesin pendingin. Pengangkutan daging beku disamping dilayani oleh kapal kargo juga dilayani oleh kapal penumpang milik PT. PELNI. Muatan ternak sapi dari NTT umumnya diangkut dengan tujuan Samarinda (Kalimantan Timur) dan Surabaya (Jawa Timur) dengan jangka waktu pelayaran dari Nusa Tenggara Timur ke Samarinda di tempuh selama 4 malam 4 hari.

Tabel 2 Alokasi dan realisasi pengeluaran ternak potong besar antar pulau selama tiga tahun 2008 - 2011 di Provinsi Nusa Tenggara Timur.

\begin{tabular}{cccccccccc}
\hline \multirow{2}{*}{ No. } & \multirow{3}{*}{ Tahun } & \multicolumn{4}{c}{ Alokasi (Ekor) } & \multicolumn{4}{c}{ Realisasi (Ekor) } \\
\cline { 3 - 10 } & & Sapi & Kerbau & Kuda & Jumlah & Sapi & Kerbau & Kuda & Jumlah \\
\hline 1 & 2008 & 40.250 & 10.000 & 6.000 & 56.250 & 63.036 & 7.745 & 7.881 & 78.662 \\
2 & 2009 & 42.750 & 10.000 & 6.000 & 58.750 & 61.814 & 7.745 & 6.696 & 76.255 \\
3 & 2010 & 47.000 & 5.800 & 5.694 & 58.494 & 49.876 & 5.704 & 4.500 & 60.080 \\
4 & 2011 & 47.000 & 5.800 & 4.500 & 57.300 & 59.670 & 3.607 & 4.153 & 67.430 \\
\hline & JUMLAH= & 177.000 & 31.600 & 22.194 & 230.794 & 234.396 & 4.892 & 23.230 & 282.427 \\
\hline
\end{tabular}

Sumber: Dinas Peternakan Provinsi Nusa Tenggara Timur, 2011

\section{Fasilitas Pelabuhan Laut dan Kesyahbandaran}

Sarana angkutan laut sendiri dapat didefinisikan sebagai satu kesatuan sistem yang terdiri atas pemanfaatan wilayah laut, kapal, fasilitas kesyahbandaran/pelabuhan, angkutan laut, navigasi transpotasi laut, keselamatan dan keamanan, lingkungan hidup, serta fasilitas penunjang dan fasilitas umum lainnya. Dalam hal transportasi ternak peranan syahbandar adalah memfasilitasi dan menangani tatacara pemuatan ternak ke kapal angkut yang ada di pelabuhan. Peryaratan yang menyangkut kesehatan ternak, bobot ternak, jumlah ternak dan persyaratan teknis lainnya sepenuhnya ada di tangan karantina ternak dan hewan-Dinas Peternakan. Sedangkan keselamatan ternak saat di perjalanan baik saat menuju kapal, saat di kapal maupun turun dari kapal sepenuhnya ada di tangan pemilik barang. Untuk menjaga ternak selama di perjalanan, pemilik ternak menugaskan petugas pengawas (Kleder) yang mengawasi ternak baik dalam hal memenuhi kebutuhan pakan, minum, kesehatan dan kebutuhan lainnya saat dalam perjalanan.

Fasilitas yang memadai yang dimiliki otoritas pelabuhan Tenau di Kupang NTT untuk menaikkan sapi ke kapal saat ini masih darurat sifatnya, sehingga proses pemuatan ternak ke dalam kapal masih mengandalkan dua hal yaitu: pertama dengan menggunakan jala, artinya untuk memasukkan sapi ke dalam kapal masih diderek dengan menggunakan jala sebagai alat angkutnya. $\underline{\text { Kedua }}$ memanfaatkan pasang surutnya air laut, pola ini digunakan untuk mengisi ternak ke palka bagian atas bila pasang surut air lautnya memungkinkan, sehingga antara permukaan kapal dengan truk sejajar.

Pemuatan ternak sapi potong mendapat prioritas utama untuk segera dilakukan pemuatan, mengingat sapi merupakan hewan yang resiko kematiannya cukup tinggi. Sehingga begitu kapal sudah sandar dan siap untuk mengangkut, sementara sapi yang akan diangkut juga sudah siap baik 
persyaratan teknis maupun administrasinya, maka proses pengangkutan akan disegerakan. Kasus di Pelabuhan Tenau - Kupang menunjukkan bahwa karena belum adanya dermaga khusus untuk sapi potong, maka selama ini proses pengangkutan ternak masih dilakukan ditempat yang sama dengan peti kemas atau barang-barang yang akan dimuat lainnya.

Peranan otoritas pelabuhan adalah berwenang memberikan tempat bagi kapal yang akan menurunkan atau menaikkan barang yang akan di angkut atau diturunkan, disamping memberikan izin kapal untuk keluar masuk pelabuhan. Lembaga otoritas Pelabuhan tidak berwenang untuk memantau isi barang yang diangkut/dimuat dalam kontainer yang akan dikirim ke tujuan tertentu. Yang dipantau hanyalah jumlah theus yang keluar maupun masuk pelabuhan. Kegiatan pengangkutan barang dengan menggunakan river container masih terbatas. Lembaga/perusahaan yang menyediakan jasa river container adalah BUP (Badan Usaha Pelabuhan). Demikian juga dalam hal penurunan ternak sapi potong, maka fihak otoritas pelabuhan telah memberikan prioritas untuk didulukan diturunkan bagi ternak hidup, sehingga baik tempat maupun waktu selalu mendapat prioritas.

\section{Perusahaan Jasa Angkutan Laut}

Binis angkutan barang melaui laut merupakan kegiatan bisnis yang menjajikan keuntungan, sehingga tidak sedikit pelaku bisnis yang bergerak dalam kegiatan tersebut. Terutama bisnis transportasi barang dari wilayah asal barang ke tempat tujuan barang yang diangkut dengan kapal lewat air baik laut maupun sungai, barang yang didalamnya termasuk ternak sapi potong. Ketentuan menunjukkan bahwa kapal untuk mengangkut ternak adalah kapal motor pengangkut ternak tergolong dalam 1 tipe dan persyaratan yang ditentukan diantaranya adalah kapasitas tampung per paddock (ruangan dalam kapal yang ditempati oleh ternak dan dibatasi oleh pagar besi serta dilengkapi dengan tempat makan, minum dan pembuangan kotoran) maksimum 25 ekor (Badan Standarisasi Nasional, 1998).

Ada tiga pelaku utama yang bergerak dalam jasa angkutan ternak/hasil ternak sapi potong melalui laut yaitu (a) jasa angkutan laut yang di lakukan oleh kapal milik pemerintah, (b) perusahaan swasta dan (c) oleh perusahaan milik perorangan. Hasil pemantauan dilapangan terhadap ketiga lembaga tersebut menunjukkan kinerja sebagai berikut :

\section{Jasa Angkutan Laut Milik Pemerintah:}

PT PELNI merupakan perusahaan angkutan milik negara yang bergerak di bidang transportasi laut. Kaitannya dengan transportasi sapi potong PT PELNI saat ini sedang merencanakan akan bergerak dibidang angkutan sapi potong hidup. Selama ini PT PELNI sudah melakukan kegiatan pengangkutan daging sapi beku terutama dari daerah produsen yang dikirim ke berbagai daerah di Indonesia. Dalam hal angkutan daging beku beku tersebut PT PELNI telah memanfaatkan disamping kapal kargo kapal juga kapal penumpang yang dilengkapi dengan fasilitas river container yaitu merupakan sarana ruang pendingin yang diperuntukkan untuk mengangkut barang-barang cepat rusak termasuk daging sapi. Sementara untuk mengangkut barang-barang lainnya lainnya telah tersedia fasilitas dray container.

Dalam menindak lanjuti rencana pengangkutan ternak sapi potong hidup, saat ini PT PELNI sedang melakukan renovasi satu unit kapal barang yaitu kapal Caraka Jaya Niaga I. Kapal ini semula merupakan kapal barang saat ini sedang mengalami docking dan sedang dalam proses perubahan fungsi yaitu semula sebagai kapal pengangkut barang dimodifikasi menjadi kapal khusus pengangkut ternak sapi potong hidup. Namun demikian fungsi kapal itu sendiri akan tetap diupayakan menjadi kapal yang dapat berfungsi sebagai kapal Tree in one. Artinya saat kapal tidak 
ada muatan ternak sapi potong, maka kapal yang bersangkutan tetap dapat difungsikan sebagai alat angkut barang lainnya. Dilihat dari segi teknis, kapal Carakan Jaya Niaga I adalah kapal buatan tahun 1986, dari perkiraan teknis setelah kapal tersebut direnovasi diperkirakan masih bisa dioperasikan selama 10 (sepuluh) tahun. Setelah mengalami renovasi sebagai kapal pengangkut ternak sapi potong hidup, diperkirakan kapasitas angkut kapal tersebut mampu mengangkut sapi hidup maksimal 800 ekor. Permasalahannya adalah: (a) Kontinuitas angkutan ternak sapi potong hidup masih kurang jelas baik dilihat dari sisi jumlah ternak yang akan diangkut maupun kelanjutan dari kegiatan tersebut. (b) Permasalahan internal perusahaan sendiri yaitu perlu mempersiapkan sumberdaya manusia yang akan menangani langsung kegiatan tersebut, terutama menyangkut pengadaan SDM yang siap pakai untuk menangani ternak selama dalam perjalanan. (c) Kurangnya fasilitas sarana penunjang di pelabuhan baik di pelabuhan pemberangkatan maupun pelabuhan tujuan ternak, terutama menyangkut fasilitas bongkar muat ternak yang sesuai dengan standar ISO atau standar kenyamanan dan keselamatan ternak (animal welfare). Untuk pengiriman daging sapi yang menggunakan jasa PT PELNI, maka persyaratan yang harus dipenuhi adalah: (a) Surat Keterangan Kesehatan Daging dari Karantina. (b) Dokumen isi muatan dari PT PELNI dan (c) Di packing menggunakan karung (seperti karung pupuk) terjahit rapi dengan kapasitas 20-25 Kg per karung.

Dalam aturan penggunaan jasa container, setiap pengguna jasa harus mencarter satu unit container. Jika kapasitasnya 20 ton, sedangkan pengirim hanya mengirim 5 ton maka pengirim harus membayar untuk kapasitas penuh. Oleh karena itu para pengguna jasa dapat berkomunikasi untuk menggunakan satu container secara bersamaan. Untuk kargo umum dengan dry container ongkos angkut dengan tonase dan kubikasi untuk tujuan Jakarta sebesar Rp 1.250 per ton atau per kubik. PT PELNI selain melayani jasa pelayaran, juga memiliki dan melayani jasa ekpedisi laut (EMKL), dan bongkar muat. Ada tiga kapal penumpang yang singgah di pelabuhan Tenau yang memiliki masing-masing dua unit refer container yaitu KM. Bukit Siguntang tujuan Makasar, Tarakan dan Nunukan; KM. Sirimau jurusan Jakarta; dan KM. Awu jurusan Surabaya. Saat ini sudah disiapkan dan ditawarkan pada Pemda NTT dan Pedagang untuk mengirim daging ke luar NTT.

Untuk Kapal angkut sapi (Kargo) kapal PT PELNI dapat berlayar pada pelabuhan yang ada di NTT seperti Tenau, Atafufu, Wini, Rote, dsb. Namun PT PELNI hanya melayani jika sekali muat dapat menyediakan 700-1.000 ekor. Jika harus mampir pada beberapa tempat dan hanya memuat 250 ekor maka membutuhkan biaya mahal dan waktu tempuh menjadi lama dapat menyebabkan penyusutan berat badan dan/atau angka kematian meningkat. Sebaiknya dengan kapasitas 700-1.000 ekor sapi di pool pada satu pelabuhan dan diturunkan pada satu pelabuhan seperti Kupang ke Jakarta. Jika Pemda dan pedagang dari NTT sudah siap tinggal menghubungi PT PELNI. Prospek pengangkutan sapi dari NTT cukup baik, karena di daerah ini sapi masih banyak dan harga lebih murah dibandingkan di Jakarta dan daerah lain. Namun Pemerintah perlu melakukan pengendalian impor untuk ternak dan daging sapi. Sebagai BUMN, PT PELNI selama ini kapal-kapal kargo yang menuju Kupang mengangkut hanya satu jurusan yaitu Kupang. Saat balik ke Surabaya atau Jakarta umumnya kapal dalam kondisi kosong. Tidak banyak hasil bumi yang dapat diangkut dari Kupang. Sebaliknya jika mengangkut ternak dengan kapal khusus ternak, maka saat keluar Kupang berisi ternak dan balik ke Kupang dalam kondisi kosong.

\section{Jasa Angkutan Laut Milik Swasta}

Kegiatan transportasi laut merupakan salah satu kegiatan bisnis transportasi yang peluangnya cukup menjanjikan, sehingga untuk menekuni kegiatan tersebut ada beberapa lembaga 
swasta yang terlibat didalamnya. Salah satu perusahaan swasta yang bergerak dalam jasa angkutan laut yang berhasil dihubungi adalah PT CBA (Citra Baru Adinusantara). Perusahaan memiliki kapal sebanyak 30 unit dengan berbagai ukuran tonase dari 500 ton sampai dengan $>1.000$ ton. Operasional pengangkutan barang yang selama ini dilakukan lebih didominasi pengangkutan barang ke Indonesia bagian timur. Usaha pengangkutan ternak sapi potong dilakukan sudah lama terutama dari daerah sentra produsen seperti NTT, NTB, Bali ke tempat-tempat yang membutuhkan terutama di kawasan timur Indonesia seperti ke Papua, Kalimantan, utamanya ke Surabaya. Kegiatan pengangkutan ternak sapi potong dari sentra produsen tersebut dilakukan lebih didasarkan perhitungan bisnis semata. Daripada kapal kembali ke Surabaya dalam keadaan kosong, maka lebih baik dimanfaatkan untuk mengangkut ternak sapi. Kegiatan pengangkutan ternak sapi potong tidak bisa dijadikan andalan, sebab disamping volumenya tidak menentu, saat ini ada kecenderungan semakin terbatas jumlah ternak yang akan diangkut, disamping jumlah kapal pesaing juga semakin meningkat.

Berdasarkan informasi dari fihak perusahaan bahwa dalam kegiatan proses pengangkutan ternak sapi potong dari NTT ke Surabaya, biaya yang dipungut pada pengguna jasa sebesar Rp 350.000/ekor sapi dan sifatnya adalah carter. Sehingga apabila kapal telah mengangkut ternak sapi potong, maka tidak bisa mengangkut barang lainnya termasuk barang hasil pertanian seperti kopra, mete atau barang hasil pertaanian lainnya. Berdasarkan hasil diskusi dengan pihak perusahaan bahwa kapal umumnya mengangkut ternak sekitar 300-400 ekor/trip. Biaya yang dikeluarkan menyangkut biaya bahan bakar (solar) sebanyak 3.500 liter dengan harga non subsidi (Rp 11.500/liter), Biaya masuk pelabuhan, biaya operasional ABK. Sehingga keuntungan yang didapat dari hasil angkut ternak secara umum hanya bisa untuk menutupi biaya operasional kapal pulang pergi dari NTT ke Surabaya. Akan tetapi kapal dari Surabaya ke NTT umumnya mengangkut semen, beras atau barang lainnya.

Tujuan utama dari kegiatan mengangkut sapi potong lebih didasarkan pada upaya menjaga hubungan bisnis yang selama ini telah dilakukan terutama dengan fihak PT Ostem Corperindo maupun dengan pelanggan-pelanggan lain yang memanfaatkan jasa pelayaran PT CBA. Prinsip bisnis yang ditempuh perusahaan dalam kegiatan pengangkutan ternak adalah kecepatan waktu dan sefety. Mengankut ternak dibutuhkan kelaikan kapal yang prima sehingga keterlambatan dalam hal waktu bisa ditekan. Disamping itu keamanan terhadap ternak harus benar-benar terjaga, sedapat mungkin ternak tidak ada yang mati dalam perjalanan. Yang masih menjadi kendala adalah hal-hal yang sifatnya post mejeur seperti cuaca tidak baik yang menyebabkan pelayaran sering ditunda.

Rute Kupang-Surabaya merupakan jalur reguler, bagi kapal kargo pengangkut container, saat kapal kembali ke Surabaya, kargo-kargo umumnya dalam keadaan kosong harus segera dibawa kembali ke Surabaya. Pengiriman sapi bukan merupakan prioritas tetapi sisa space kargo yang ada. Kemudian pengguna jasa dan pihak angkutan kapal melakukan negosiasi harga. Jika sesuai maka sapi dapat diangkut. Dengan demikian system yang digunakan tidak menggunakan system carter, sedangkan rute Kupang - Samarinda tidak ada yang reguler, sehingga transaksi jasa kapal menggunakan system carter. Sementara jenis biaya yang harus dikeluarkan diantaranya : (a) Bahan bakar 100 liter per jam Rp 11.500 per liter, (b) Tenaga kerja 16 orang gaji antara Rp 1,5 juta s/d Rp 5 juta per bulan, (c) Tambat labuh Rp 20.000 per hari, (c) Makan ABK Rp 25.000 per hari, (d) Asuransi Rp 117.000 per hari, (e) Air bersih 5 ton per hari Rp 35.000 per ton, (f) Dock dua tahun sekali antara Rp 300 juta - Rp 1 milyar (tergantung kerusakan), (g) Sewa kapal tunda, kapal pandu dan biaya penungguan antrian $=\mathrm{Rp} 2.000 .000$, dan (h) Pemeriksaan dan sertifikasi kapal $\mathrm{Rp}$ 250.000 per tahun 


\section{Perusahaan Angkutan laut Milik Perorangan:}

Berdasarkan klasifikasi kapal maka kapal laut yang digunakan untuk mengangkut ternak terdiri dari dua jenis kapal yaitu (a) kapal mesin berbahan baku besi dan (b) kapal layar motor (KLM) yang umumnya berbahan baku kayu. Dalam Sistem angkutan ternak sapi potong dengan menggunakan kapal kayu sampai saat ini masih tetap berjalan dimana kapal kayu tersebut mampu melayari sampai ke lokasi tujuan yang berada di pedalaman dengan menyusuri sungai daerahdaerah tertentu. Yang menjadi permasalahan adalah faktor keamanan pelayaran yang harus mendapat perhatian terutama apabila kapal tersebut berlayar di tengah laut. Kapal kayu mampu beroperasi sampai ke Kalimantan dan tempat-tempat lain, hal ini dapat dilakukan dengan cara berlayar dengan menyusuri wilayah-wilayah dekat pantai, agar keselamatan kapal dapat terjaga, artinya dalam perjalanannya kapal tersebut senantiasa akan berusaha menyusuri pantai sehingga tidak akan terlalu jauh dari garis pantai.

Tabel 3 : Kebutuhan biaya operasional kapal layar Motor (KLM)/trip, thn 2013

\begin{tabular}{|c|c|c|c|c|c|c|}
\hline No & $\begin{array}{l}\text { Uraian peruntukan biaya } \\
\text { yang harus dikeluarkan }\end{array}$ & Satuan & $\begin{array}{c}\text { Biaya ke } \\
\text { Surabaya (Rp) }\end{array}$ & $\begin{array}{r}\text { Komposisi } \\
\text { biaya }(\%)\end{array}$ & $\begin{array}{c}\text { Biaya ke } \\
\text { anjarmasin (Rp) }\end{array}$ & $\begin{array}{c}\text { Komposisi } \\
\text { biaya }(\%)\end{array}$ \\
\hline 1 & Gaji ABK & Rp/rit & 15.000 .000 & 20.59 & 20.000 .000 & 22.77 \\
\hline 2 & Ransum ABK & $\mathrm{Rp} / \mathrm{rit}$ & 5.000 .000 & 6.86 & 5.000 .000 & 5.69 \\
\hline 3 & Solar 6000 ltr a'Rp7000 & $\mathrm{Rp} / \mathrm{rit}$ & 42.000 .000 & 57.66 & 51.000 .000 & 58.06 \\
\hline 4 & Oli 60 ltr a'Rp28.000 & Rp/rit & 1.680 .000 & 2.31 & 1.680 .000 & 1.91 \\
\hline 5 & Asuransi & $\mathrm{Rp} / \mathrm{rit}$ & 0 & 0.00 & 0 & 0.00 \\
\hline 6 & Penyusutan & $\mathrm{Rp} / \mathrm{rit}$ & Tdk dihitung & 0.00 & Tdk dihitung & 0.00 \\
\hline 7 & Docking & $\mathrm{Rp} / \mathrm{rit}$ & 411.000 & 0.56 & 411.000 & 0.47 \\
\hline 8 & Perawatan di laut & $\mathrm{Rp} /$ rit & 5.000 .000 & 6.86 & 5.000 .000 & 5.69 \\
\hline 9 & Pungutan tak resmi & $\mathrm{Rp} / \mathrm{rit}$ & 2.250 .000 & 3.09 & 3.250 .000 & 3.70 \\
\hline 10 & Ijin di Pelabuhan & $\mathrm{Rp} /$ rit & 1.500 .000 & 2.06 & 1.500 .000 & 1.71 \\
\hline \multicolumn{3}{|c|}{ Total biaya } & 72.430 .411 & 100.00 & 87.430 .411 & 100.00 \\
\hline
\end{tabular}

Tujuan pelayaran dengan membawa ternak sapi potong selain ke Surabaya adalah ke Banjarmasin. Kapal kayu yang berangkat dari pelabuhan asal seperti Bima maupun Lembar dengan tujuan Banjarmasin umumnya selain membawa sapi juga memawa hasil pertanian lainnya seperti bawang merah, kedelai dan garam. Sementara kapal yang berangkat dari tujuan asal Bima atau Lembar dengan tujuan Surabaya umumnya membawa jagung, kedelai dan sapi sifatnya hanya kadang-kadang. Sapi-sapi yang dating ke Surabaya baik yang berasal dari Nusa Tenggara Barat maupun dari Nusa Tenggara Timur kemudian dilanjutkan diangkut dengan truk tronton menuju Jakarta, sehingga dapat dikatakan Surabaya hanya merupakan kota transit bagi ternak-ternak sapi potong tersebut. Selanjutnya kapal-kapal yang semula memuat sapi ke Surabaya, maka sebaliknya dari Surabaya menuju Bima, Lembar maupun Kupang umumnya mengangkut berbagai jenis barang hasil industry seperti semen, bahan kelontong, sparepart mupun barang-barang elektronik.

Menurut informasi bahwa ukuran kapal antara 125-150 GT, jika memuat barang termasuk sapi dan lainnya ongkos yang diterima sekitar Rp 90 juta lebih. Ini berarti jika biaya perjalanan Rp 87,84 juta maka pengusaha kapal laut masih untung 2,16 juta walaupun kapal balik dari Banjarmasin ke Bima dalam keadaan kosong. Demikian juga jika kapal hanya angkut jagung dan kedele dari Bima ke Surabaya ongkos yang diterima 4.500 x $7.000=\operatorname{Rp} 31,5$ juta, ini berarti untuk rute Surabaya ada kemungkinan merugi atau keuntungan relative kecil. Keragaan dilapangan memang menunjukkan bahwa kapal kayu dari pelabuhan Bima dan Lembar memang lebih banyak menuju ke Banjarmasin. Sebagai catatan bahwa pengusaha lebih suka menggunakan kapal kayu karena biaya operasional relatif murah. 
Hasil pengamatan dilapangan menunjukkan bahwa penggunaan kapal kayu sebagai pengangkut ternak sapi memang telah dirancang secara khusus oleh pemiliknya untuk angkutan sapi, yaitu terdiri dari dua dek, masing-masing dilengkapi pintu untuk jalan keluar-masuknya sapi. Uji kelayakan kapal dalam usaha pengangkutan ternak sapi ditentukan oleh syahbandar terutama didasarkan atas data luas ruangan, ketersediaan air, ketersediaan pakan selama perjalanan, serta pengawal/penjaga sapi dalam perjalanan. Disamping itu pihak Syahbandar menentukan jumlah sapi yang dapat diangkut berdasarkan ketersediaan ruangan di kapal. Kecuali kelaikan kapal untuk sapi, Syahbandar juga bertanggung jawab terhadap keselamatan pelayaran, dalam kaitannya dengan ramalan kondisi klimatologi terutama keadaan hujan, angin dan cuaca pada jalur-jalur yang akan dilalui oleh kapal tersebut.

Khusus untuk pelabuhan Lembar bahwa kedatangan kapal kayu tidak terjadwal dengan

rutin, sehingga bagi pemilik sapi yang akan mengirim ternak ke luar provinsi seperti ke Banjarmasin atau ketempat tujuan lainnya umumnya harus menyewa kapal dari luar. Karena kapal tsb umumnya datang ke Lembar dalam kondisi kosong maka biaya sewa kapal menjadi tinggi. Hal ini tentu berimplikasi terhadap harga jual ternak sapi, artinya tingginya harga sapi tersebut bukan karena harga beli ditingkat produsen, tetapi lebih disebabkan karena biaya transportasi yang mahal.

Kondisi dilematis seperti ini sudah berlangsung cukup lama dan indikasi untuk adanya perbaikan harga tampaknya belum ada. Seperti diketahui bahwa dalam bisnis ternak sapi potong maupun bisnis barang lainnya, pedagang tentu berprinsip bahwa berusaha untuk memperoleh keuntungan, sehingga meskipun biaya transportasi sapi keluar provinsi cukup mahal, mereka akan tetap menekuni usahanya, selama tetap memperoleh keuntungan. Dalam kondisi seperti ini, pemikiran untuk memberi subsidi angkutan sapi tampaknya sangat diperlukan, agar harga ternak tidak terlalu berat dirasakan oleh konsumen maupun peternak produsen.

\section{Ekspedisi Angkutan Laut}

Dalam upaya meningkatkan kinerja transportasi laut terutama dalam sistem pengangkutan barang termasuk sapi potong, peranan ekspedisi laut sangat diutamakan. Ekspedisi laut merupakan lembaga bisnis yang bergerak dalam bidang jasa pengantar barang dari tempat asal barang sampai ke tempat tujuan. Lembaga ini tidak saja dapat memperlancar usaha pengiriman barang dari suatu tempat asal barang ke tempat tujuan barang, akan tetapi juga merupakan lembaga yang mampu menjembatani antara pengguna jasa angkutan dan pemilik sarana angkutan kapal laut.

Kegiatan tranportasi ternak sapi potong lewat laut dengan menggunakan kapal, maka peran jasa ekspedisi menjadi penting artinya. Lembaga ini merupakan lembaga yang bergerak dalam jasa pengiriman barang, dimana sejak ternak mulai keluar dari karantina dan masuk ke kapal hingga turun ke pelabuhan tujuan bahkan sampai ke alamat tujuan, maka peran jasa ekspedisi sangat penting. Kaitannya dengan pengiriman ternak sapi potong, disamping mengantarkan ternak dari pelabuhan asal sampai ke pelabuhan tujuan ternak, lembaga ekspedii bertangung jawab terhadap keselamatan barang selama dalam perjalanan. Dalam kenyataannya, usaha ekspedisi dapat merangkap sebagai pengusaha kapal dan memiliki kapal sendiri disamping dapat menggunakan kapal milik perusahaan lain, disamping perusahaan ini biasanya juga memiliki gudang sendiri bahkan armada angkutan truk dan container. Dimana kontainer yang digunakan berupa container kering (dry container) maupun container basah (rifer container).

Di sisi lain ada perusahaan ekspedisi yang memiliki container dingin (refer container) selain container kering (dray container), untuk container dingin pengenaan biaya lebih mahal dari pada container kering. Dalam hal kegiatan pengangkutan daging sapi potong maupun daging ternak 
lainnya, saat ini belum ada perusahaan yang menggunakan jasa container basah tersebut. Pengiriman daging basah dalam jumlah banyak yang berasal dari NTT masih sulit dilakukan sehubungan pengiriman ternak maupun hasil ternak sapi potong dari NTT ke luar wilayah NTT lebih didominasi oleh pengiriman ternak sapi hidup. Kalaupun ada kegiatan pengiriman daging sapi, umumnya masih dalam jumlah yang sedikit dan ini dilakukan dengan menggunakan cargo pesawat terbang. Disamping lebih cepat maka biayanya lebih murah.

Informasi menunjukkan bahwa biaya sewa container dingin dari Kupang ke Surabaya mencapai Rp 18 juta rupiah. Ada tiga perusahaan ekspedisi yang memiliki container refer yaitu: PT. Haga Jaya, PT. Trasindo Buana Sentosa dan PT. Rahayu. Besarnya biaya kirim ditentukan juga oleh harga barang. Daging sapi dan ikan termasuk barang mahal sehingga biaya kirim lebih mahal dibandingkan mengangkut barang dengan harga murah seperti kunyit. Selain itu pengiriman daging sapi harus menggunakan refer container, dimana pengiriman dengan container dingin harus mengikutkan tenaga teknisi dari pemilik container dingin untuk memonitor dan mengendalikan temperature dalam container agar tetap dingin sehingga barang yang dikirim tidak rusak akibat system pendingin rusak. Jika hal itu terjadi pengguna jasa akan melakukan complain dengan nilai yang cukup besar.

Ada dua mekanisme penentuan biaya yang dilakukan oleh lembaga ekspedisi yaitu (a) berdasarkan tonase yang lebih diarahkan ke berat barang dan (b) kubikase lebih ditekankan pada volume barang. Untuk kelompok barang yang tergolong berat dalam penentuan biaya digunakan cara mengukur berat tonasenya dengan besarnya biaya Rp 500 per Kg. Sementara untuk kelompok barang ringan perhitungan biaya didasarkan atas kubikasi dengan besarnya biaya Rp 425.000 per meter kubik $\left(\mathrm{m}^{3}\right)$. Kegiatan packaging dan bahan packing dilakukan dan biayanya ditanggung pemilik barang atau pengguna jasa ekspedisi. Bagi pengguna jasa ekspedisi, hal-hal yang harus dilengkapi adalah dokumen pengiriman berupa surat jalan. Selain itu hal-hal yang perlu dilakukan oleh pihak ekspedisi sebelum mengirim barang adalah: (a) Menentukan jenis barang yang akan dikirim, untuk menentukan masuk kategori ringan atau berat. (b) Dilihat apakah barang berbahaya atau tidak, sehingga perlu adanya perlakukan khusus bagi barang yang sifatnya khusus. (c) Nama dan alamat pengirim maupun nama dan alamat penerima barang.

Salah satu kasus perusahaan ekspedisi pengiriman ternak sapi potong dari Kupang ke Surabaya atau ke Banjarmasin adalah PT Ostem Corporindo. Dimana perusahaan tersebut merupakan perusahaan jasa ekpedisi pelayaran nasional atau merupakan agen Cargo (Pengangkut) ternak sapi potong hidup yang melayani pengangkutan ternak dari NTT (Kupang) lewat pelabuhan Tenau diangkut ke Surabaya maupun ke Samarinda. Perusahaan jasa angkutan laut tersebut merupakan perusahaan yang dimanfaatkan oleh pengusaha ternak besar dari Jakarta. Sementara untuk membantu kelancaran proses pengangkutan ternak dari wilayah provinsi Nusa Tenggara Timur yang keluar daerah (Surabaya dan Samarinda), fihak PT Ostem Corporindo menyewa kapal dari PT. CBA (Citra Baru Adinusantara) merupakan perusahaan pemilik kapal yang berdomosili di Surabaya.

Menurut informasi bahwa saat ini proses pengangkutan sapi melalui pelabuhan Tenau (Nusa Tenggara Timur) ke Surabaya maupun ke Samarinda sudah tidak ada lagi yang menggunakan kapal kayu melainkan kapal besi. Dalam proses pengangkutan ternak ke tempat tujuan disamping harus berbekal surat keterangan dari karantina, maka untuk pengawasan kesehatan dan keamanan ternak diperlukan petugas pengawas (cleder) yang bertugas untuk memberikan pakan dan minuman kepada ternak disamping juga mengawasi kondisi ternak saat dalam perjalanan di laut. Keragaan dilapangan menunjukkan bahwa dalam realisasinya sistim 
Bambang Winarso: Peran Angkutan Laut dalam Meningkatkan Distribusi Ternak Sapi Potong...

pengangkutan ternak di kapal besi masih menggunakan kandang darurat yaitu sekat-sekat kandang yang dibuat dari bambu. Ada 13 kapal yang sering dimanfaatkan oleh PT Ostem Corporindo dalam mengangkut ternak sapi potong (Tabel 4).

Tabel 4 Nama dan karakteristik kapal yang sering dimanfaatkan oleh PT Ostem Corporindo, Thn 2013

\begin{tabular}{clcllcccc}
\hline No & $\begin{array}{c}\text { Nama Kapal } \\
\text { (KM.) }\end{array}$ & Thn & GT/NT & Panjang & Lebar & Dalam & Kapasitas & $\begin{array}{c}\text { Overall } \\
\text { Length }\end{array}$ \\
\hline 1 & Citra Mellenium & 1971 & $630 / 372$ & 52,55 & 9,30 & 4,90 & 1.100 & 56,75 \\
2 & Heng-heng & 1977 & $1209 / 638$ & 65,26 & 11,20 & 6,27 & 1.900 & 70,60 \\
3 & Lintas Nusantara & 1983 & $634 / 308$ & 43,05 & 12,20 & 4,90 & 800 & 49,00 \\
4 & Lintas Papua & 1986 & $1261 / 589$ & 55,35 & 13,50 & 6,00 & 1.900 & 60,80 \\
5 & Multi Abadi & 1987 & $1237 / 549$ & 57,23 & 13,50 & 6,22 & 2.000 & 62,20 \\
6 & Melinda-01 & 1989 & $638 / 192$ & 46,18 & 11,00 & 5,10 & 1.000 & 54,88 \\
7 & Mega Abadi & 1991 & $555 / 186$ & 44,30 & 9,35 & 4,70 & 750 & 48,30 \\
8 & Permata Abadi & 1988 & $662 / 199$ & 48,53 & 10,30 & 5,30 & 900 & 53,30 \\
9 & Selvi Utami & 1986 & $1349 / 652$ & 57,46 & 13,50 & 6,00 & 2.000 & 63,00 \\
10 & Selvi Pratiwi & 1989 & $657 / 252$ & 45,60 & 10,60 & 5,30 & 1.050 & 49,25 \\
11 & Shanelin K & 1982 & $482 / 227$ & 42,72 & 8,00 & 5,00 & 650 & 46,85 \\
12 & Tifelin K & 1980 & $484 / 205$ & 42,57 & 8,00 & 5,20 & 650 & 45,95 \\
13 & Atria Nusantara & 1984 & $1372 / 758$ & 68,50 & 11,80 & 6,80 & 2.000 & 73,60 \\
\hline
\end{tabular}

Sumber : PT Ostem Corporindo Cabang Kupang, 2013.

\section{TUJUAN TERNAK}

Sapi potong yang di angkut dari wilayah sentra produksi baik dari wilayah Provinsi Nusa Tenggara Barat, Nusa Tenggara Timur maupun Bali sebagian besar di angkut menuju wilayah konsumen terutama provinsi Kalimantan Timur, Jawa Barat dan DKI Jakarta. Ternak yang ditujukan untuk wilayah kawasan konsumen di provinsi-provinsi di Pulau Kalimantan umumnya langsung diangkut melalui laut ke lokasi tujuan baik di Provinsi Kalimantan Selatan, Kalimantan Barat mupun Kalimantan Timur. Akan tetapi sapi potong yang akan dikirim ke wilayah Jawa Barat dan wilayah Jabodetabek (Jakarta, Bogor, Depok dan Bekasi) bahkan ke Sukabumi umumnya dari wilayah produsen diangkut dengan kapal laut dan transit diistirahatkan di Surabaya (pelabuhan Kalimas) selanjutnya diangkut dengan truk ke tujuan konsumen di Jabodetabek. Sehingga untuk pengangkutan sapi dari NTT, NTB maupun Bali dengan tujuan Jabodetabek dan sekitarnya umumnya menggunakan dua moda transportasi yaitu laut dan darat.

Dari kegiatan pengiriman ternak sapi potong khususnya ternak sapi yang ditujukan ke wilayah konsumen di Jabodetabek, masalah kegiatan transit ternak tentu membawa dinamika tersendiri. Kasus di dermaga Kalimas sebagai tempat transit ternak sapi potong menunjukkan bahwa dalam usaha penurunan ternak sapi potong dari kapal selama ini telah ditempuh dengan tiga cara yaitu (a) sapi diangkut dan diturunkan dari kapal menggunakan jala, (b) sapi langsung digiring melalui jembatan sementara terutama saat permukaan laut sama dengan permukaan dek kapal dan (c) ternak diturunkan dengan menggunakan kontainer yang bisa dibuka dan ditutup bagian depan dan belakang. Cara ketiga sedang dalam proses percobaan, akan tetapi mengalami kesulitan terutama saat memasukkan sapi ke dalam kontainer. Akan tetapi sehubungan dengan banyaknya kritik yang berkaitan dengan prinsip Animal welfare, mau tak mau pola ketiga harus dilaksanakan walau pada kenyataannya membutuhkan waktu lama yang pada akhirnya membutuhkan biaya pembongkaran lebih mahal. Sebagai perbandingan dalam menurunkan sapi potong sebanyak 300 
Jurnal Penelitian Pertanian Terapan

ekor, maka dengan cara (a) membutuhkan waktu 8 jam, dengan cara (b) membutuhkan waktu 5-6 jam hal ini sebagai akibat harus menunggu truk yang akan mengangkut. Sedangkan cara (c) bisa memakan waktu sampai dengan 12 jam. Informasi yang menunjukkan beberapa kapal pengangkut ternak yang telah melakukan kegiatan pembongkaran ternak dengan cara masing-masing disajikan dalam tabel 5 .

Tabel 5 Kegiatan pembongkaran hewan ternak di Pelabuhan Kalimas Surabaya tahun 2013

\begin{tabular}{|c|c|c|c|c|c|}
\hline Nama Kapal & $\begin{array}{c}\text { Perusahaan Angkutan } \\
\text { Laut }\end{array}$ & Hewan & $\begin{array}{c}\text { Asal } \\
\text { Ternak }\end{array}$ & $\begin{array}{c}\text { Jumlah } \\
\text { (Ekor) }\end{array}$ & Alat Bongkar \\
\hline KM.. KAMBERRA & $\begin{array}{l}\text { PT. Pelayaran Armada } \\
\text { Mandiri }\end{array}$ & sapi & Waingapu & 253 & Kotak dimodifikasi \\
\hline KM.. METRO EXPRESS & PT. Namsurya Citrasari & sapi & Kupang & 150 & Jembatan / Titian \\
\hline KM.. MULTI PERMAI & PT. Namsurya Citrasari & sapi & Kupang & 110 & Kotak dimodifikasi \\
\hline KM.. CALYPSO & $\begin{array}{l}\text { PT. Suntraco Intim } \\
\text { Transport }\end{array}$ & sapi & Kupang & 55 & Kotak dimodifikasi \\
\hline KM.. SAKURA 09 & $\begin{array}{l}\text { PT. Suntraco Intim } \\
\text { Transport }\end{array}$ & sapi & Kupang & 100 & Kotak dimodifikasi \\
\hline \multirow[t]{2}{*}{ KM.. KALIMAS I } & \multirow[t]{2}{*}{ PT. Bumi Indah Line } & sapi & Kupang & 246 & \multirow[t]{2}{*}{ Kotak dimodifikasi } \\
\hline & & Kuda & Kupang & 82 & \\
\hline \multirow[t]{2}{*}{ KM.. DANDELION } & \multirow[t]{2}{*}{$\begin{array}{l}\text { PT. Suntraco Intim } \\
\text { Transport }\end{array}$} & sapi & Waingapu & 189 & \multirow[t]{2}{*}{ Kotak dimodifikasi } \\
\hline & & Kerbau & Waingapu & 23 & \\
\hline \multirow[t]{2}{*}{ KM.. MITRA KANOWE } & \multirow[t]{2}{*}{$\begin{array}{l}\text { PT. Pelayaran Armada } \\
\text { Mandiri }\end{array}$} & sapi & Waingapu & 143 & \multirow[t]{2}{*}{ Kotak dimodifikasi } \\
\hline & & Kuda & Waingapu & 107 & \\
\hline \multirow[t]{2}{*}{$\begin{array}{l}\text { KLM.NUSANTARA } \\
\text { INDAH }\end{array}$} & \multirow[t]{2}{*}{ PT. Sepakat Adiwisesa } & sapi & Bima & 63 & \multirow[t]{2}{*}{ Jembatan / Titian } \\
\hline & & Kerbau & Bima & 39 & \\
\hline KM.. MITRA KONAWE & PT. Armada mandiri & sapi & Waingapu & 206 & Kotak dimodifikasi \\
\hline KM.. FUJIYAMA & PT. Armada mandiri & sapi & Waingapu & 214 & Kotak dimodifikasi \\
\hline $\begin{array}{l}\text { KLM CAHAYA } \\
\text { NIRMALA }\end{array}$ & PT. Cahaya Buana Setia & sapi & Badas & 129 & Jembatan / Titian \\
\hline \multirow[t]{2}{*}{ KLM. ALAM MAKM.UR } & \multirow[t]{2}{*}{ PT. Kalimas Paruga } & sapi & Bima & 85 & \multirow[t]{2}{*}{ Jembatan / Titian } \\
\hline & & Kerbau & & 10 & \\
\hline KLM. DUTA MULYA & $\begin{array}{l}\text { PT. Samudera Buana } \\
\text { Persada }\end{array}$ & sapi & Bima & 30 & Jembatan / Titian \\
\hline KLM. KAMBERRA & PT. Armada mandiri & sapi & Waingapu & 304 & Kotak dimodifikasi \\
\hline \multirow[t]{2}{*}{ KLM. KARTIKA BUANA } & \multirow[t]{2}{*}{$\begin{array}{l}\text { PT. Samudera Buana } \\
\text { Persada }\end{array}$} & sapi & Badas & 100 & \multirow[t]{2}{*}{ Jembatan / Titian } \\
\hline & & Kuda & Badas & 3 & \\
\hline KM.. MEGAH PRATAMA & $\begin{array}{l}\text { PT. Sinar Siendra } \\
\text { Pratama }\end{array}$ & sapi & Kupang & 220 & Kotak dimodifikasi \\
\hline $\begin{array}{l}\text { KM.. LESTARI PERMAI } \\
\text { III }\end{array}$ & $\begin{array}{l}\text { PT. Arnita Persada Indo } \\
\text { Lines }\end{array}$ & sapi & Atapupu & 261 & Jala-Jala \\
\hline \multirow{4}{*}{ JUMLAH } & & Kerbau & & 10 & \\
\hline & & SAPI & & 2.858 & \\
\hline & & Kuda & & 192 & \\
\hline & & Kerbau & & 73 & \\
\hline
\end{tabular}

Sumber : Badan Otorita Pelabuhan Tanjung Perak Surabaya, 2013 
Bambang Winarso: Peran Angkutan Laut dalam Meningkatkan Distribusi Ternak Sapi Potong...

Informasi dari Badan otorita Pelabuhan Tanjung Perak menunjukkan bahwa kegiatan bongkar-muat di Pelabuhan Kalimas satu tahun terakhir (2012) menunjukkan bahwa aktifitas pembongkaran angkutan ternak sapi hidup kiriman dari NTT, NTB maupun Bali lebih dominan. Ini berarti bahwa kegiatan pengiriman ternak sapi hidup dari Jawa Timur melalui pelabuhan Kalimas tidak ada sama sekali. Sementara kegiatan pembongkaran muatan ternak sapi hidup sendiri lebih didominasi oleh kapal laut intersuler yang umumnya menggunakan kapal besi. Dimana selama periode tahun 2012 pembongkaran ternak yang diangkut melalui kapal laut intersuler sekitar 13, 36 ribu ekor. Sedangkan ternak sapi potong yang diangkut melalui kapal rakyat yang umumnya menggunakan kapal kayu hanya 1,86 ribu ekor (Tabel 6).

Tabel 6 Kegiatan bongkar muat ternak sapi potong di pelabuhan Kalimas, Surabaya Thn 2012

\begin{tabular}{clcccccccc}
\hline \multirow{2}{*}{ No. } & \multirow{2}{*}{ Bulan } & \multicolumn{9}{c}{ Uraian Bongkar Muat Hewan } \\
\cline { 3 - 9 } & & \multicolumn{2}{c}{ Samudera } & \multicolumn{2}{c}{ Intersuler } & \multicolumn{2}{c}{ Rakyat } & \multicolumn{2}{c}{ Jumlah } \\
\cline { 3 - 9 } & Bongkar & Muat & Bongkar & Muat & Bongkar & Muat & Bongkar & Muat \\
\hline 1 & Januari & 0 & 0 & 384 & 0 & 115 & 0 & 499 & 0 \\
2 & Pebruari & 0 & 0 & 671 & 0 & 0 & 0 & 671 & 0 \\
3 & Maret & 0 & 0 & 655 & 0 & 25 & 0 & 680 & 0 \\
4 & April & 0 & 0 & 931 & 0 & 0 & 0 & 931 & 0 \\
5 & Mei & 0 & 0 & 1.537 & 0 & 0 & 0 & 1.537 & 0 \\
6 & Juni & 0 & 0 & 691 & 0 & 0 & 0 & 691 & 0 \\
7 & Juli & 0 & 0 & 1.219 & 0 & 113 & 0 & 1.332 & 0 \\
8 & Agustus & 0 & 0 & 1.383 & 0 & 0 & 0 & 1.383 & 0 \\
9 & September & 0 & 0 & 1.214 & 0 & 130 & 0 & 1.344 & 0 \\
10 & Oktober & 0 & 0 & 2.1 & 0 & 1.058 & 0 & 3.158 & 0 \\
11 & Nopember & 0 & 0 & 854 & 0 & 89 & 0 & 943 & 0 \\
12 & Desember & 0 & 0 & 1.727 & 0 & 338 & 0 & 2.065 & 0 \\
\hline
\end{tabular}

Sumber : Badan Otorita Pelabuhan Tanjung Perak Surabaya, 2013

\section{KESIMPULAN}

Dalam kegiatan pemasaran ternak sapi potong khususnya proses distribusi, beberapa wilayah propinsi di Indonesia merupakan lumbung ternak nasional sekaligus berperan sebagai pemasok, diantaranya adalah Jawa Timur, Bali, Nusa Tenggara Timor dan Sulawesi Selatan. Disisi lain beberapa wilayah seperti DKI Jakarta, Jawa Barat dan wilayah lainnya justru merupakan wilayah potensial sebagai konsumen. Permasalahannya bahwa jarak antara wilayah produsen hasil ternak dengan wilayah konsumen sangat berjauhan dan tranportasi lewat laut merupakan proses pengangkutan yang membutuhkan waktu panjang. Jarak yang jauh disamping berpengaruh terhadap biaya yang ditimbulkan juga berpengaruh terhadap kesehatan ternak. Angkutan laut sebenarnya merupakan solusi efektif, akan tetapi belum ditunjang oleh fasilitas yang memadai, baik sarana kapal angkut maupun sarana yang ada di pelabuhan. Usaha pengangkutan lewat laut merupakan kegiatan bisnis yang cukup menjanjikan, akan tetapi belum tergarap secara maksimal. 
Jurnal Penelitian Pertanian Terapan

\section{DAFTAR PUSTAKA}

Badan Standarisasi Nasional, Pusat Standarisasi dan Akreditasi. Standar Nasional Indonesia.1998. Kapal Motor Untuk Mengangkut Ternak Sapi dan Kerbau.

Badan Otorita Pelabuhan Tanjung Perak, Surabaya, 2013

Dinas Peternakan Propinsi Nusa Tenggara Timur, 2011; Laporan Tahunan

Keputusan Gubernur Nusa Tenggara Timur No. 278/Kep/HK/2011 Tentang Alokasi Pengeluaran Ternak Besar Potong Di Provinsi Nusa Tenggara Timur Thn 2012

Keputusan Gubernur Nusa Tenggara Timur No. 207/Kep/HK/2012 Tentang Tambahan Alokasi Pengeluaran Ternak Besar Potong Di Provinsi Nusa Tenggara Timur Thn 2012.

Willem Nikson (2009). Kebijakan Keselamatan dan Keamanan Transportasi Laut. Badan Koordinasi Keamanan Laut Republik Indonesia.

PT Pelabuhan Indonesia III (Persero). Laporan tahunan 2009 s/d

Ilham dan Yusmichad Yusdja, 2012. Sistem Transportasi Perdagangan Ternak Sapid an Implikasi Kebijakan Di Indonesia. Analisis Kebijakan Pertanian Vol. 2 no. 1. Pusat Sosial Ekonomi dan Kebijakan Pertanian. Badan Litbang Pertanian.

Nyak Ilham, 2009. Kebijakan Pengendalian Harga Daging Sapi Nasional. Analisis Kebijakan Pertanian Vol. 7 no. 3. Pusat Sosial Ekonomi dan Kebijakan Pertanian. Badan Litbang Pertanian.

Tjeppy D. Soedjana, Umar Bamualim, Uum Umiyasih dan Armiadi Semali. 1995. Studi Transportasi Ternak Potong dari Nusa Tenggara Timur dan Jawa Timur ke Jakarta. Jurnal Penelitian No. 2. Pusat Penelitian dan Pengembangan Peternakan. Badan Litbang Pertanian.

Yusmichad Yusdja dan Nyak Ilham, 2004. Tinjauan Kebijakan Pengembangan Agribisnis Sapi Potong. Analisis Kebijakan Pertanian Vol. 2 no.2. Pusat Sosial Ekonomi dan Kebijakan Pertanian. Badan Litbang Pertanian. 